\title{
PEMANFAATAN POTENSI LOKAL LEMBAGA PENDIDIKAN MADRASAH SEBAGAI PEMBELAJARAN USAHA PRODUKTIF
}

\author{
Irawati Dinasari $\mathbf{R}^{1)}$, Siti Saroh ${ }^{2)}$ Sumartono ${ }^{3)}$ \\ ${ }^{1}$ Fakultas Peternakan, Universitas Islam Malang \\ email: irawati.dinasari12@yahoo.com \\ ${ }^{2}$ Fakultas IImu Administrasi, Universitas Islam Malang \\ email: ulilamri 2307@yahoo.co.id \\ ${ }^{3}$ Fakultas Peternakan, Universitas Islam Malang \\ email: Sumartono 56@yahoo.com
}

\begin{abstract}
Pemanfaatan potensi lokal dan sarana yang dimiliki untuk mengembangkan kemampuan kewirausahaan peserta didik harus didudukung oleh wawasan pengetahuan dan kepakaran para pengelola, guru dan pengurus yang menjadi pembinanya. Tujuan penelitian ini adalah 1) Mengetahui kemampuan Pengelola, guru, pengurus dan peserta didik madrasah dalam memahami pemanfaatan potensi lokal yang dimiliki. 2) Mengetahui kemampuan pengelola, guru, pengurus dan peserta didik dalam memahami pengetahuan manajemen usaha dan jiwa kewirausahaan. 3) Mengetahui kemampuan pengelola, pengurus dan peserta didik setelah mengikuti pendidikan dan pelatihan budidaya kelinci dan demo membuat produk pengolahan daging kelinci. Metode yang digunakan dengan rancangan eksperimental, tahapan yang dilakukan di awali survey, ceramah, pelatihan, bimbingan dan demo, FGD partisipatif serta wawancara, dievaluasi. Hasilnya meliputi 1) kepala sekolah menjadi memahami pemanfaatan potensi yang dimiliki. 2) guru dan pengurus madrasah memperoleh tambahan wawasan dan memahami bagaimana membekali pengetahuan dan pengalaman pada peserta didik yang berbasis potensi yang dimiliki madrasah untuk bekal kemandirian masa depan 3)bagi peserta didik memberi motivasi dan semangat untuk lebih berprestasi dalam kegiatan sekolah dan merupakan peluang memperoleh tambahan ilmu yang selama ini belum pernah ada selama sekolah.
\end{abstract}

Keywords: $\quad$ potensi lokal, pengelola madrasak,kewirausahaan, peserta didik

\section{PENDAHULUAN}

Lembaga pendidikan madrasah merupakan usaha pengembangan dan penyempurnaan kegiatan proses belajar mengajar dalam upaya untuk menampung pertumbuhan, perkembangan ilmu pengetahuan, jumlah peserta didik yang semakin meningkat, dan bertambah setiap tahun ajaran. Madrasah memiliki karakteristik khas yang tidak dimiliki oleh model pendidikan lainnya, sehingga menjadi salah satu tumpuan harapan bagi manusia modern untuk mengatasi keringnya hati dari nuansa keagamaan dan menghindarkan diri dari fenomena demoralisasi dan dehumanisasi yang semakin merajalela seiring dengan kemajuan peradaban teknologi dan materi. 
Mencapai standar keberhasilan lembaga pendidikan Madrasah, maka peran guru dalam proses pembelajaran sangat menentukan. Menurut hasil forum Carnegie tentang pendidikan dan ekonomi (Arends et al.,2001), di abad informasi ini terdapat sejumlah kemampuan yang harus dimiliki oleh guru dalam pembelajaran. Kemampuan-kemampuan tersebut, adalah memiliki pemahaman yang baik tentang kerja baik fisik maupun sosial, memiliki rasa dan kemampuan mengumpulkan dan menganalisis data, memiliki kemampuan membantu pemahaman siswa, memiliki kemampuan mempercepat kreativitas sejati siswa, dan memiliki kemampuan kerja sama dengan orang lain.

Madrasah Aliyah dan Madrasah Tsanawiyah Al-Hayatul Islamiyah merupakan madrasah yang dimiliki oleh yayasan Al-Hayatul Islamiah dan bangunannya berada dalam lingkungan pondok pesantren. Sarana yang tersedia cukup lengkap, meliputi; bangunan masjid, rumah tinggal, bangunan sekolah/madrasah, koperasi, kantin, perpustakaan, area sekolah alam, bumi perkemahan, stodio musik, lapangan olah raga, laboratorium komputer dan internet. Selain itu disekitar bangunan Madrasah Aliyah dan Madrasah Tsanawiyah Al-Hayatul Islamiyah masih terdapat tanah kosong cukup luas yaitu seluas $6000 \mathrm{~m}$ yang selama ini belum dioptimalkan pemanfaatannya.

Sarana tersebut adalah sangat ideal sebagai tempat mengembangkan pendidikan yang berorientasi kewirausahaan (entrepreneurship). Sehingga diharapkan peserta didik menjdi sosok sumberdaya manusia berkualitas, berakhlaq al-karimah dan setelah lulus diharapkan dapat madiri, hidup yang bermartabat serta akan memiliki modal untuk membantu pembangunan di desa masing-masing.

Peserta didik di Madrasah Aliyah dan Madrasah Tsanawiyah Al-Hayatul Islamiyah berasal dari berbagai pelosok pedesaan di Indonesia dan sebagian besar mereka berasal dari keluarga miskin. Jumlah total peserta didik tahun 2014 di Madrasah Aliyah sebanyak 221 orang dan Tsanawiyah sebanyak 111 orang.

Tujuan penelitian ini adalah 1)Mengetahui kemampuan Pengelola, guru, pengurus dan peserta didik madrasah dalam memahami pemanfaatan potensi lokal yang dimiliki. 2) Mengetahui kemampuan pengelola, guru, pengurus dan peserta didik dalam memahami pengetahuan manajemen usaha dan jiwa kewirausahaan. 3) Mengetahui kemampuan pengelola, pengurus dan peserta didik setelah mengikuti pendidikan dan pelatihan budidaya kelinci dan demo membuat produk pengolahan daging kelinci.

\section{KAJIAN LITERATUR}

Manajemen usaha dibutuhkan untuk mencapai baik dari aspek profit maupun tujuan lain sesuai yang diinginkan oleh pihak pengelola bisnis. Beberapa hal yang menjadi patokan utama manajemen usaha diantaranya adalah terkait dengan manajemen produksi dan manajemen pemasaran. Manajemen produksi merupakan pengelolaan dan perencanaan terkait 
penggunaan sumber daya- sumber daya dalam proses transfortasi bahan baku menjadi bahan jadi yang siap dipasarkan pada sebuah perusahaan bisnis (Handoko, 2002).

Manajemen usaha di bidang produksi menyangkut bagaimana proses produksi itu bisa berlangsung dengan baik sehingga mampu menghasilkan produk. Hasil produksi agar dapat dikonsumsi oleh konsumen, maka manajemen usaha memerlukan kegiatan pemasaran. Kegiatan pemasaran merupakan aktivitas pertukaran, dimana seseorang berusaha menawarkan sejumlah barang atau jasa dengan sejumlah nilai untuk memenuhi kebutuhannya.

Menurut Kotler dan Armstrong (2008) Pemasaran adalah suatu proses sosial dan manajerial dimana pribadi atau organisasi memperoleh apa yang mereka butuhkan dan inginkan melalui penciptaandan pertukaran nilai dengan yang lain. Pemasaran memiliki peran penting dalam sebuah bisnis, karena pemasaran dapat membantu memberikan informasi mengenai barang atau jasa yang ditawarkan sebuah perusahaan, sehingga dapat memenuhi kebutuhan dan keinginan konsumen sesuai dengan sasaran pasar. Karena produk barang atau jasa akan memiliki nilai jual yang lebih tinggi, jika dapat menyediakan apa yang konsumen butuhkan.

Pemenuhan kebutuhan dan keinginan konsumen membutuhkan konsep pemasaran yang biasa disebut dengan istilah marketing mix. Marketing mix merupakan kombinasi dari empat variable penting dari konsep pemasaran yang dapat dikendalikan oleh perusahaan. Empat variable tersebut meliputi produk ( product), harga ( price), tempat ( place), dan promosi ( promotion), dan biasa disingkat dengan 4P.

1. Product adalah segala sesuatu (barang atau jasa ) yang ditawarkan kepada konsumen untuk mendapatkan perhatian, pembelian, atau dikonsumsi guna memenuhi kebutuhan dan keinginan masyarakat. Tidak hanya kualitas produk yang dibutuhkan konsumen, namun sistem pelayanan yang diberikan dan desain produk yang menarik juga akan memberikan nilai lebih pada konsumen untuk membeli atau mengkonsumsi suatu produk.

2. Price adalah sejumlah uang yang harus dibayar konsumen untuk mendapatkan sebuah produk atau jasa. Price dapat juga diartikan sebagai nilai tukar untuk memperoleh keuntungan dari produk atau jasa yang dibutuhkan. Harga merupakan salah satu variable marketing mix yang bersifat fleksibel, terkadang bisa stabil dalam beberapa waktu dengan harga tertentu namun bisa juga tiba - tiba meningkat atau turun tajam disesuaikan degan kondisi permintaan pasar.

3. Place, merupakan kegiatan bisnis untuk membuat produk atau jasa yang ditawarkan lebih mudah terjangkau oleh konsumen, dan dapat tersedia pada sasaran pasar yang tepat. Variabel tempat juga meliputi saluran distribusi untuk menjangkau konsumen yang tersebar luas. 
Sehingga beberapa perusahaan membuka kantor cabang di daerah daerah untuk memudahkan konsumennya.

4. Promotion adalah kegiatan untuk memperkenalkan suatu produk atau jasa pada pasar sasaran, untuk membangun persepsi pelanggan mengenai produk atau jasa yang ditawarkan. Konsep promosi yang biasa digunakan antara lain advertising, public relation, sales promotion, personal selling, serta direct marketing.

Manajemen usaha selain berhubungan dengan manajemen produksi dan pemasaran dalam menjalankan fungsinya, juga harus didukung dengan kemampuan kewisausahaan. Kewirausahaan berhubungan dengan suatu sikap, jiwa dan kemampuan untuk menciptakan sesuatu yang baru yang sangat bernilai dan berguna bagi dirinya dan orang lain. Kewirausahaan merupakan sikap mental dan jiwa yang selalu aktif atau kreatif berdaya, bercipta, berkarsa dan bersahaja dalam berusaha dalam rangka meningkatkan pendapatan dalam kegaitan usahanya atau kiprahnya. Menurut Suryana (2003) pengertian kewirausahaan mengandung maksud bahwa seorang wirausahan adalah orang yang memiliki kemampuan untuk menciptakan sesuatu yang baru dan berbeda (create new and different), tidak hanya dimiliki oleh pebisnis tetapi dapat dimiliki oleh setiap orang yang berfikir kreatif dan bertindak kreatif. Hal ini seperti pandangan Kasmir (2007), kewirausahaan sebagai suatu proses penerapan kreativitas dan inovasi dalam memecahkan persoalan dan menemukan peluang untuk memperbaiki kehidupan (bisnis).

Ciri dan watak kewirausahaan antara lain adalah: (1) percaya diri keyakinan, ketidaktergantungan, individualistis, dan optimisme; (2) berorientasi pada tugas dan hasil; (3) Kebutuhan untuk berprestasi, berorientasi laba; (4) ketekunan dan ketabahan, tekad kerja keras; (5) mempunyai dorongan kuat, energetik dan inisiatif; (6) pengambilan resiko kemampuan untuk mengambil resiko yang wajar dan suka tantangan; (7) kepemimpinan perilaku sebagai pemimpin, bergaul dengan orang lain, menanggapi saran-saran dan kritik; (7) keorisinilan inovatif dan kreatif serta fleksibel; (8) berorientasi ke masa depan pandangan ke depan, perspektif (Suryana, 2003).

Seorang yang memiliki jiwa dan sikap wirausaha selalu tidak puas dengan apa yang telah dicapainya. setiapi waktu, dari hari ke hari, dari minggu ke minggu dan seterusnya selalu mencari peluang untuk meningkatkan usaha dan kehidupannya. Wirausahawan selalu berkreasi dan berinovasi tanpa berhenti, karena dengan berkreasi dan berinovasi akan nenemukan peluang peluang dalam bisnisnya. Wirausaha adalah orang yang terampil memanfaatkan peluang dalam mengembangkan usahanya dengan tujuan untuk meningkatkan kehidupannya 


\section{METODE PENELITIAN}

Penelitian ini dilakukan dengan rancangan eksperimental. Pada tahap awal dilakukan survey untuk memperoleh gambaran nyata calon sasaran penelitian, kemudian sasaran terpilih diberikan pengetahuan dan pengalaman melalui ceramah, pelatihan, bimbingan dan demo lalu untuk memperdalam diagnosis, dilakukan FGD partisipatif serta wawancara mendalam. Setiap kegiatan dievaluasi sampai tujuan penelitian ini tercapai.

\section{HASIL DAN PEMBAHASAN}

Madrasah yang berada dilingkungan pondok pesantren Al-Hayatul Islamiah ini sebetulnya memiliki potensi untuk mendukung peserta didik mengembangkan kompetensinya, namun belum tergali secara mendalam sehingga belum muncul kepermukaan. Potensi yang dapat dikembangkan antara lain; 1) sumber daya manusia yang dapat dipersiapkan menjadi kaderkader dalam bidang ekonomi produktif disamping mempunyai kemampuan dibidang ilmu agama, 2) pemanfaatan lahan kosong sebagai media pembelajaran kewirausahaan bagi peserta didik, 3) pemanfaatan sarana yang tersedia untuk pengembangan kreatifitas berfikir dan mengasah berbagai keterampilan, seperti; masjid, rumah tinggal, bangunan sekolah/madrasah, koperasi, kantin, perpustakaan, area sekolah alam, bumi perkemahan, stodio musik, lapangan olah raga, laboratorium komputer dan internet.

Berbagai potensi yang tersedia di lembaga pendidikan madrasah ini, dapat digunakan untuk menggodok para peserta didik tidak hanya melahirkan pemikir agama tetapi juga dapat mencetak pemikir sosial, politik dan ekonomi, serta dimasa akan datang peserta didik dapat membantu pemerintah dalam menyebarluaskan inovasi pembangunan dan sebagai wadah ekonomi bagi masyarakat.

Berdasar potensi yang terdapat dilingkungan Madrasah Aliyah dan Tsanawiyah, maka Usaha-usaha yang dialukan program IbM ini antara lain; 1) studi banding ke peternak kelinci, sapi dan kambing yang mengikut sertakan kepala madrasah, guru dan pengurus; 2) pendidikan dan pelatihan manajemen usaha, kewirausahaan di bidang budidaya ternak kelinci yang diikuti mulai dari kepala sekolah, guru, pengurus serta peserta didik dengan mendatangkan tenaga ahli yaitu ketua asosiasi kelinci; 3) demo pengolahan daging kelinci dimasak menjadi bakso dan naget, 4) pengadaan kandang kelinci dan bibit kelinci.

Budidaya kelinci dapat dilakukan oleh siapa saja teruma bagi yang masih mengannggur, mereka yang berada dalam tekanan kemiskinan dan yang ingin meningkatkan pendapatan. Menurut Manshur (2009), beternak kelinci sama dengan ternak uang. Tiada yang tersisa dari setiap elemen kelinci. Baik daging, bulu atau pesona tubuhnya masing-masing memiliki manfaat luar biasa sehingga layak mendapat harga tinggi. Termasuk feses dan urin juga luar biasa manfaatnya yaitu dapat dirubah menjadi pupuk organik. 
Salah satu peluang bisnis sekarang ini adalah budidaya kelinci dan ikutannya, karena daging kelinci sebagai alternatif lauk-pauk yang mempunyai kandungan nutrisi, rendahnya kandungan kolesterol dan natrium, sehingga membuat daging kelinci sangat dianjurkan sebagai makanan untuk pasien penyakit jantung, usia lanjut, dan mereka yang bermasalah dengan kelebihan berat badan. Keuntungan lainnya, tulang pada kelinci lebih tipis, dagingnya halus, dan seratnya pendek sehingga mudah dikunyah. Selain itu, modal uang beternak kelinci murah, lahan yang diperlukan tidak perlu luas.

Beragam jenis kelinci yang berkembang, terdapat kelinci untuk piaraan (hobi) dan kelinci penghasil daging berkualitas. Daging kelinci memiliki kandungan proteinnya tinggi (25\%), rendah lemak (4\%), dan kadar kolesterol daging juga rendah yaitu $1,39 \mathrm{~g} / \mathrm{kg}$. Kandungan lemak kelinci hanya $8 \%$, sedangkan daging ayam, sapi, domba, dan babi masing-masing 12\%, 24\%, $14 \%$, dan $21 \%$. Kadar kolesterolnya sekitar $164 \mathrm{mg} / 100$ gram daging, sedangkan ayam, sapi, domba, dan babi berkisar $220-250 \mathrm{mg} / 100 \mathrm{gram}$ daging.

Berdasar ceramah dari nara sumber ketua assosiasi peternak kelinci kabupaten Malang yaitu bapak Winarto secara gamblang dan lengkap dipaparkan sebagai berikut:

\section{Keunggulan beternak kelinci}

a. Kelinci memiliki potensi biologis yang sangat tinggi, dapat dikawinkan kapan saja asal sudah dewasa, beranak banyak dan waktu bunting pendek, pertumbuhan cepat, dapat memanfaatkan hijauan dan produk limbah secara efisien.

b. Daging kelinci baik untuk kesehatan karena kandungan protein tinggi tetapi kolestrol dan sodium rendah, sehingga dapat meningkatkan kecerdasan anak-anak dan mencegah penyumbatan pembuluh darah pada orang dewasa

c. Daging kelinci mengandung: protein 20,8\%; lemak 10,2\%; kadar air $67,9 \%$ dan kadar kalori 7,3\%. Kandungan asam lemak linoleat tertinggi diantara lemak lainnya yaitu $22,5 \%$; kandungan kolesterol relatif rendah yaitu $0,1 \%$.

d. Kelinci juga menghasilkan bahan baku kulit dalam waktu relatif singkat, jumlah banyak dan bernilai ekonomis tinggi untuk industri, seperti: industri pakaian bulu, selendang, topi, tas wanita, boneka cinderamata dan kerajinan lain yang harganya mahal.

e. Kotoran kelinci (feses dan urine) dapat dimanfaatkan sebagai pupuk, karena mengandung kadar $\mathrm{N}, \mathrm{P}, \mathrm{K}$ yang tinggi dan sebagai media pertumbuhan cacing. Sedangkan cacing dapat dimanfaatkan untuk protein ransum bagi ternak.

f. Tidak membutuhkan tempat atau lahan yang luas, modal yang relatif kecil, mudah beradaptasi,mudah dipelihara, pakan tidak tergantung bahan baku import. 


\section{Peluang pasar}

a. Kelinci hidup:

- Bibit

- Hewan percobaan

- Hewan kesayangan dan lain-lain.

b. Pangan:

- Sate dan gulai kelinci

- Abon, steak dan burger

- Bakso, sosis dan naget dll.

c. Industri kulit/bulu:

- wool garment

- Tas, dompet, jaket, sandal dan sepatu

- Gantungan kunci, topi dan boneka

- sarong ( HP, remote control, stik golf)

d. Limbah kelinci:

- pupuk organik berupa pupuk kandang

- pupuk cair.

\section{Permasalahan dan kendala}

a. pembibitan

- Masih terbatas ketersediaan bibit unggul

- Bibit yang ada cenderung bukan bibit murni

- Program pembibitan masih bersifat tradisional, sehingga seleksi persilangan dan recording belum berjalan dengan baik.

b. Teknologi budidaya:

- Teknologi pakan belum dipahami (jenis pakan, nutrisi dan volume)

- Beum tersedianya kelembagaan budidaya kelinci.

c. Pengolahan Hasil:

- Teknologi pengolahan pasca panen belum dipahami

4. faktor penentu keberhasilan beternak kelinci

a. Seleksi induk:

- Pemilihan induk yang baik, betina umur10 bulan dan jntan berumur 11-12 bulan

- Waktu perkawinan sampai waktu melahirkan harus dicatat

b. Perkandangan:

- Perkandangan dan perlengkapan dalam berternak kelinci sangat tergantung pada lokasi, situasi, tingkat usaha dan modal. Tiap peternak memiliki problem dan tujuan tersendiri dalam berternak.

- Bentuk dan ukuran kandang yang akan dibangun, sebaiknya memperhatikan kemudahan dalam bekerja, mengontrol, kehematan waktu dan tenaga dalam pengolahannya. Kandang yang baik memiliki andil yang tinggi dalam keberhasilan beternak kelinci, karena berperan pada stabilitas kesehatan dan prodiktifitas kelinci 
- Ukuran kandang berdasr jenis umur kelinci adalah:

1) Type ringan, yakni: $P \times L \times T=50 \times 60 \times 40 \mathrm{~cm}$.

2) Type sedang, yakni: $P \times L \times T=60 \times 70 \times 50 \mathrm{~cm}$.

3) Type berat, yakni: $P \times L \times T=70 \times 80 \times 60 \mathrm{~cm}$.

4) Ukuran kotak sarang beranak: $P \times L \times T=60 \times 70 \times 50 \mathrm{~cm}$

- Syarat pembuatan kandang

1) Kandang cukup sinar matahari

2) Hindari becek dan terpaan angina langsung.

3) Aman dari serangan hama kucing dan tikus.

4) Lantai kandang renggang dan sanitasi lancar.

5) Tempat makan bersentrat terbuat dari semen atau alumunium agar mudah dalam pembersihannya.

6) Tempat minum dari botol atau repel otomatis supaya tidak terinjak kaki kelinci guna pencegahan penyakit.

7) Setidaknya kandang berada dibawah naungan pohon

C. Pakan:

Formula pakan konsentrat kelinci ditujukan pada Tabel 5.

Tabel 5

\begin{tabular}{|l|r|l|c|}
\hline \multicolumn{2}{|c|}{ Formula pakan 1 } & \multicolumn{2}{|c|}{ Formula pakan 2 } \\
\hline $\begin{array}{l}\text { Nama } \\
\text { Pakan }\end{array}$ & Jumlah & $\begin{array}{l}\text { Nama } \\
\text { Pakan }\end{array}$ & $\begin{array}{c}\text { Jumla } \\
\text { h }\end{array}$ \\
\hline $\begin{array}{l}\text { Jagung } \\
\text { giling }\end{array}$ & $15 \mathrm{~kg}$ & $\begin{array}{l}\text { Dedak } \\
\text { halus / } \\
\text { bekatul }\end{array}$ & $35 \mathrm{~kg}$ \\
\hline Bekatul & $30 \mathrm{~kg}$ & $\begin{array}{l}\text { Jagung } \\
\text { giling }\end{array}$ & $20 \mathrm{~kg}$ \\
\hline Polar & $25 \mathrm{~kg}$ & Polar & $20 \mathrm{~kg}$ \\
\hline $\begin{array}{l}\text { Bungkil } \\
\text { kelapa }\end{array}$ & $14 \mathrm{~kg}$ & $\begin{array}{l}\text { Bungkil } \\
\text { kelapa }\end{array}$ & $18 \mathrm{~kg}$ \\
\hline $\begin{array}{l}\text { Lecetan } \\
\text { kedelai }\end{array}$ & $10 \mathrm{~kg}$ & $\begin{array}{l}\text { Tepung } \\
\text { tulang }\end{array}$ & $5 \mathrm{~kg}$ \\
\hline $\begin{array}{l}\text { Bungkil } \\
\text { kedelai }\end{array}$ & $5 \mathrm{~kg}$ & Garam & $1 \mathrm{~kg}$ \\
\hline garam & $1 \mathrm{~kg}$ & mineral & $1 \mathrm{~kg}$ \\
\hline
\end{tabular}

Masing-masing formula pakan dicampur dan diaduk sampai bahan tercampur dengan rata. Penghematan dapat dilakukan denganmenurunkan harga bisa ditambah ampas tahu dengan perbandingan $5 \mathrm{~kg}$ aampas tahu dengan $3 \mathrm{~kg}$ campuran konsentrat diatas.

\section{Pengembangbiakan Kelinci}

Kelinci betina mengalami masa subur $4-7$ hari sekali. Pada dasarnya kelinci betina dapat dikawinkan kapan saja setelah beranak. Bilaman vulva betina telah berwarna merah juka dikawinkan maka kebuntingan kelinci akan 90\% sebaliknya jika vulva berwarna pucat maka tingkat kebuntingan hanya $10 \%$. Ovulasi atau pelepasan telur terjadi 
setelah perkawinan dan pembuahan berlangsung 10 jam setelah perkawinan. Hal-hal yang perlu diperhatikan adalah:

a. Waktu kawin yang baik adalah pukul $06.00-08.00$ dan pukul $19.00-21.00$

b. Perkawinan dilakukan pada kandang jantan

c. Pastikan telah terjadi $2-3$ kali ejakulasi pejantan saat dikawinkan, ditandai dengan suara yang khas dan terjatuhnya pejantan saat enjakulasi

d. guna menyakinkan, bila perlu dilakukan perkawinan lagi $4-7$ hari setelah perkawinan pertama. Biasanya kalau terjadi kebuntingan betina/induk akan melakukan penolakan saat dikawinkan disertai suara kruk-kruk.

Masa kebuntingan kelinci bervariasi antara 28-33 hari. Hal-hal yang perlu diperhatikan dalam perawatan induk yang bunting:

a. Berikan makan dan minum yang cukup.

b. jamin ketenangan situassi kandang

c. Tidak memindahkan induk yang bunting ke kandang lain guna menghindari stress

d. siapkan kotak sarang beranak bila usiakebuntingan induk menapai 25 hari Kelahiran dan perawatan:
a. Tambahkan jerami kering pada sarang beranak sebelum melahirkan
b. Beberapa jam sebelum melahirkan induk mencabuti bulunya sendiri guna membuat sarang. Beberapa kasus induk tidak mau mencabuti bulunya, oleh karena itu perlu dicarikan jemari.
c. Bila anak berserakan saat kelahitan kumpulkan dengan alat bantu tanpa menyentuh anak kelinci yang baru lahir
d. anak kelinci akan terbuka matanya pada malam hari pada usia 11 - 13 hari dan akan turun dari sarang pada hari ke 18 untuk mencari makanan.

\section{Hama dan pengendalian penyakit.}

- Bisul

Penyebab: terjadinya pengumpulan darah kotor di bawah kulit.

Sasaran: pangkal ekor, punggung, leher dan telinga bagian belakang.

Tanda-tanda: bintik-bintik berisi cairan semacam bisul pada permukaan kulit.

Pencegahan : disinfektan kandang, sanitasi kandang baik, pembersihan dan pemotongan kuku secara berkala terutama pada jenis kelinci bulu panjang.

Pengobatan

: memandikan kelinci dengan sabun belerang ditambah dengan salep, dan anti biotik guna pencegahan infeksi sekunder. 
- Kudis

Penyebab : Darcoptes scabiei.

Sasaran: sekitar mata, hidung dan jari- jari kaki

Tanda-tanda : daerah terserang bersisik, mengeras, warnakulit kemerahan, bulu rontok, selalu menggaruk-garuk

Pencegahan : disinfektan kandang, santitasi kadang baik, mencegah kontak langsung dengan hewan yang sakit, peguburan / pembakaran bangkai hewan yang terserang.

Pengobatan : memandikan kelinci dengan larutan asuntal, neuguvon, odylen, enjeksi dengan prepara infermectin.

- Kangker telinga

Penyebab : tengu warna merah muda.

Sasaran : telinga

Tanda-tanda :

Daun telinga muncul seperti kerak warna coklat dan mengeluarkan cairan berbau, telinga luka, kurus, kejang dan hilang keseimbangan, nafsu makan menurun bahkan hilang sama sekali.

Pencegahan :

Kandang bersih dan tidak lembab, isolasi dan pisahkan hewan yang sakit

Pengendalian :

injeksi dengan preparat Avermecfit.

- Penyakit kulit kepala

Penyebab: jamur.

Gejala : : timbul semacam sisik pada kepala.

Pengendalian : dengan bubuk belerang.

- Penyakit mata

Penyebab: bakteri dan debu.

Gejala : : mata basah dan berair terus.

Pengendalian : dengan salep mata

- Mastitis

Penyebab : : susu yang keluar sedikit/tak dapat keluar.

Gejala : puting mengeras dan panas bila dipegang.

Pengendalian : dengan tidak menyapih anak terlalu mendadak.

- Pilek

Penyebab : virus

Gejala : : hidung berair terus

Pengendalian : penyemprotan antiseptik pada hidung.

- Radang paru-paru

Penyebab : bakteri Pasteurella multocida.

Gejala : napas sesak, mata dan telinga kebiruan.

Pengendalian : diberi minum Sul-Q-nox.

- Berak darah

Penyebab : protozoa Eimeira. 
Gejala

: nafsu makan hilang, tubuh kurus, perut membesar dan mencret darah.

Pengendalian : diberi minum sulfaquinxalin dosis $12 \mathrm{ml}$ dalam 1 liter air.

- Hama pada kelinci umumnya merupakan predator dari kelinci seperti anjing. Pada umumnya pencegahan dan pengendalianhama dan penyakit dilakukan dengan menjaga kebersihan lingkungan kandang, pemberian pakan yang sesuai dan memenuhi gizi dan penyingkiran sesegera mungkin ternak yang sakit.

\section{Pascapanen}

- Stoving

Kelinci dipuasakan 6-10 jam sebelum potong untuk mengosongkan usus. Pemberian minum tetap .

- Pemotongan

Pemotongan dapat dengan 3 cara:

1) Pemukulan pendahuluan, kelinci dipukul dengan benda tumpul pada kepala dan saat koma disembelih.

2) Pematahan tulang leher, dipatahkan dengan tarikan pada tulang leher. Cara ini kurang baik.

3) Pemotongan biasa, sama seperti memotong ternak lain.

- Pengulitan

Dilaksanakan mulai dari kaki belakang ke arah kepala dengan posisi kelinci digantung.

- Pengeluaran Jeroan

Kulit perut disayat dari pusar ke ekor kemudian jeroan seperti usus, antung dan paru-paru dikeluarkan. Yang perlu diperhatikan kandung kemih jangan sampai pecah karena dapat mempengaruhi kualitas karkas.

- Pemotongan Karkas

Kelinci dipotong jadi 8 bagian, 2 potong kaki depan, 2 potong kaki belakang, 2 potong bagian dada dan 2 potong bagian belakang. Presentase karkas yang baik $49-52 \%$.

\section{Analisis ekonomi budidaya}

Analisa Usaha Budidaya, perkiraan analisis budidaya kelinci didasarkan pada jumlah ternak per 20 ekor induk:

- Biaya ProduksiKandang dan perlengkapan Rp. 1.000.000,-Bibit induk 20 ekor @ Rp. 30.000, Rp.600.000,

- Pejantan 3 ekor @ Rp. 20.000,- Rp.60.000,-

- Pakan

Sayur + rumput Rp. 1.000.000,-Konsetrat (pakan tambahan) Rp. 2.000.000,-

- Obat Rp. 1.000.000,- 
- Tenaga kerja 2 x 12 x Rp. 150.000,- Rp.3.600.000,-

- Jumlah biaya produksi Rp. 9.260.000,

- Pendapatan

Kelahiran hidup/induk/tahun $=31$ ekor Penjualan : Bibit: $20 \times 15$

x Rp.20.000,- Rp.6.000.000,

Kelinci potong $20 \times 15$ × Rp. 50.000,-Rp. 15.000.000,Feses/kotoran Rp. 60.000,-Bulu Rp. 750.000,- Jumlah pendapatan Rp. 21.810.000,-Keuntungan Rp. 12.550.000,Parameter kelayakan usaha : $\mathrm{B} / \mathrm{C}$ ratio $=2,36$

\section{Pengolahan daging kelinci}

Merujuk pada artikel tentang pengolahan kelinci secara panjang lebar dijelaskan sebagai berikut; Pengolahan merupakan hal yang harus diperhatikan, karena dengan pengolahan akan menentukan apakah produk olahan tersebut diterima atau tidak oleh konsumen. Proses pengolahan pangan, penggunaan panas untuk membunuh mikroba yang tidak diinginkan juga akan merusak zat nutrisi yang ada di dalam bahan pangan itu sendiri, oleh karena itu perlu mencari titik optimasi untuk mendapatkan bahan pangan dengan tingkat kerusakan nutrisi yang rendah namun aman untuk dikonsumsi.

Pada pemasakan daging harus diperhatikan adanya keseimbangan antara tingginya suhu dan lamanya pemanasan, karena penggunaan panas yang tinggi dengan jangka waktu yang lama dapat menyebabkan perubahan cita rasa serta degradasi termal komponen kimiawi pangan yang pada akhirnya dapat menyebabkan terjadinya penurunan kualitas. Pengolahn daging kelinci agar dapat diterima oleh masyarakat serta dalam rangka upaya diversifikasi pangan hewani maka perlu dilakukan proses pengolahan, karena proses pengolahan menyebabkan terjadinya perubahan fisik maupun kimiawi sehingga mengakibatkan terbentuknya aroma, konsistensi, tekstur, nilai gizi dan penampakan yang diharapkan dapat merubah faktor kebiasaan makan. Mutu akhir dari makanan ini sangat ditentukan oleh mutu bahan baku dan kondisi proses oleh karena itu dalam pengolahan bahan pangan faktor tersebut harus mendapat perhatian, disamping itu harus memperhatikan pula preferensi konsumen, khususnya dalam pengolahan daging kelinci.

Produk olahan daging kelinci banyak macamnya antara lain bakso, sosis, nugget, abon dan dendeng. Olahan tersebut adalah produk olahan yang telah lama dikenal masyarakat dan mempunyai masa simpan yang panjang. Oleh karena itu melalui teknologi pengolahan tersebut diharapkan daging kelinci dapat diterima konsumen, yang dapat meningkatkan gizi masyarakat. Akhirnya dapat menumbuh kembangkan peternakan kelinci. Karakteristik daging kelinci yang lebih mendekati daging ayam dibandingkan dengan daging dari ternak ruminansia lainnya, menjadikan daging kelinci dapat diolah menjadi berbagai macam olahan seperti produk olahan daging ayam. 
Berikut ini adalah pengolahan bakso dan nugget daging kelinci, yang dikutip dari yaitu sebagai berikut;

Bakso kelinci (BACl)

Bahan :

250 gr daging kelinci segar

$75 \mathrm{gr}$ es batu

8 gr garam dapur Penyedap rasa secukupnya 0,5 gr mrica

25 gr tepung tapioka

0,75 gr STP (sodium tripoly pospat).

Cara membuat :

Buang lemak dan jaringan ikat (urat) yang menempel pada daging kelinci, kemudian tambahkan garam dan es yang telah dihaluskan selama satu menis. Masukkan tepung tapioka, mrica ke dalam adonan daging, kemudian putar selama satu menit. Adonan yang telah lengket didiamkan selama 30 menit sampai 1 jam (kalau bisa simpan di lemari es) Rebus air dalam panci sampai mendidih, setelah itu kecilkan api atau matikan. Siapkan adonan dan bentuk menjadi bulatan sesuai selera, masukkan ke dalam panci yang berisi air panas. Bulatan bakso akan mengembang dan berubah warna menjadi coklat keabuan, kemudian rebus lagi selama 10-15 menit. Tiriskan dan bakso siap untuk dimakan atau diolah menjadi berbagai jenis menu makanan atau disimpan.

Nugget kelinci (NUCl)

Bahan :

$1 \mathrm{~kg}$ daging kelinci

35 gr susu krim

$20 \mathrm{gr}$ bawang putih

10 gr lada

15 gr gula

$1 \mathrm{gr} \mathrm{MSG} \mathrm{(monosodium} \mathrm{glutamate)}$

25 gr meizena

$1 \mathrm{~kg}$ minyak goreng

75 gr es batu

Garam dan penyedap rasa secukupnya

Cara membuat :

Daging digiling hingga halus, kemudian campurkan dengan $25 \mathrm{gr}$ meizena, 35 gr susu krim, $75 \mathrm{gr}$ es batu, $20 \mathrm{gr}$ bawang putih, $10 \mathrm{gr}$ lada dan $1 \mathrm{gr}$ MSG. Adonan dicetak dalam lembaran plastik dan dimasukkan ke dalam lemari es selama 30 menit. Setelah itu adonan dipotong-potong dan dicelupkan dalam perekat tepung yang terbuat dari campuran $80 \mathrm{gr}$ meizena, $2 \mathrm{gr}$ bawang putih, $1 \mathrm{gr}$ lada, $1 \mathrm{gr}$ garam, dan $300 \mathrm{ml}$ air. Setelah itu nugget dilumuri dengan tepung roti dan dilakukan penggorengan awal (digoreng setengah matang). Kemas nugget dalam vakum dan simpan pada suhu rendah. Jika akan dimakan nuget digoreng selama empat menit. 
Pelaksanaan program pengabdian ini, setiap tahapan dilakukan monitoring dan evaluasi terutama pada waktu kegiatan pembinaan, pelatihan dan demontrasi. Hal ini dilakukan untuk mengidentifikasi pencapaian target dan hambatan-hambatan yang muncul, sehingga dapat segera diperbaiki.

Selama FGD peserta sangat aktif dan semangat mengajukan pertanyaanpertanyaan terhadap semua materi yang disampaikan dan kasus-kasus yang pernah dialami bagi peserta didik yang pernah melakukan budidaya kelinci . Sehingga hal-hal yang terkait dengan dampak-dampak ternak kelinci, yang selama ini menjadi hambatan memperoleh penjelasan jalan keluarnya.

Demikian pula, ketika demo pengolahan masak para peserta secara bergilir mencoba mempraktekan pembuatan bakso dan nugget, sampai hasilnya bagus. Selama pelaksanaan pelatihan dan praktek ketrampilan tidak ada hambatan yang berarti, bahkan setelah mencoba hasil olahan daging kelinci para peserta didik saling berebut untuk menikmati kelezatan olahan daging kelinci.

Hasil pelaksanan Program IbM madrasah berwirausaha ini mendapat respon yang sangat baik dari peserta program, antara lain:

1)respon dari kepala sekolah yaitu program lbM ini membuka wawasan pemikiran yang lebih luas, dimana sebelumnya tidak terfikirkan bahwa potensi yang dimiliki oleh madrasah ini sebaiknya dimanfaatkan untuk apa. 2) respon dari guru dan pengurus madrasah bahwa membekali pengetahuan dan pengalaman pada peserta didik dapat dilakukan dengan menggali potensi yang dimiliki pihak madrasah kemudian diramu dengan kemampuan berkreasi baik dari guru, pengurus dan terutama kemampuan yang dimiliki peserta didiknya, sehingga menghasilkan karya yang bermanfaat untuk kemandirian masa depan peserta didik. 3) respon bagi peserta didik program IbM ini memberi motivasi dan semangat untuk lebih berprestasi dalam kegiatan sekolah dan merupakan peluang memperoleh tambahan ilmu yang selama ini belum pernah ada selama sekolah.

\section{KESIMPULAN}

Pengelola, guru dan pengurus madrasah semakin memahami tentang pemanfaatan potensi yang dimiliki untuk mengembangkan kreatifitas peserta didik serta mengoptimalkan pemanfaatan lahan kosong yang selama ini belum difungsikan..

Melalui pendidikan dan pelatihan memberi wawasan mengenai manajemen usaha dan tambahan keterampilan bagi peserta didik sebagai motivasi tumbuhnya jiwa kewirausahaan, mengarahkan kompetensi yang dimiliki. Sehingga kelak setelah lulus dapat mandiri dan menciptakan lapangan pekerjaan.

Pengetahuan budidaya kelinci merupakan pengetahuan yang baru bagi sebagian sumberdaya manusia di lingkungan madrasah, terutama bagi peserta didik. Dilihat dari respon selama mengikuti pendidikan dan pelatihan menunjukan semangat yang tinggi untuk mengikuti mulai kegiatan awal 
sampai kegiatan terakhir. Hal ini dapat digunakan sebagai bekal diri untuk berdikari dimasa depan dan dapat berpartisipasi dalam pembangun perekonomi ketika hidup ditengah-tengah masyarakat

\section{REFERENSI}

Handoko, T. Hani. 2002. Dasar-Dasar ManajemenProduksi dan Operasi, Yogyakarta, BPFE, Kasmir. 2007. Kewirausahaan. Jakarta, PT.Raja Grafindo Perkasa, Kotler, Philip - Gary Armstrong. 2008. Prinsip - Prinsip Pemasaran, Jakarta, Erlangga, Manshur, Faiz. 2009. Ternak Kelinci = Ternak Uang, (www.tanimaju.wordpress.com), Suryana, 2003. Kewirausahaan: Pedoman Praktis, Kiat dan Proses Menuju Sukses, Jakarta, Salemba Empat 